\title{
Six pre-colonial Portuguese shipwrecks identified on the South African coast: the legacy of Bartolomeu Dias
}

\author{
Malcolm Turner* \\ 10 Laura Road St Francis Bay, South Africa 6312
}

For hundreds of years European merchants had undertaken successful trade missions to the eastern markets; crossing overland, they operated from the city states of Genoa, Pisa, Amalfi and Venice. When the overland route was blocked by the Ottoman Turks, an alternative route was planned. To the rulers of Spain and Portugal, the only possibility was to find a sea route to the east, and a sea route around Africa was considered feasible by the rulers of Portugal. Under the guidance of Prince Henry of Portugal, the son of Joao I, the coast of Africa was slowly explored. By 1483 CE Diego Cao had reached Cape Cross on the desolate Namibian coast. Joao II, sanctioned the next expedition, which was led by Bartolomeu Dias, who left Lisbon in $1487 \mathrm{CE}$. His instructions were to go round the southern tip of Africa and attempt to establish contact with Prester John, the mythical Christian king, whose cooperation was considered essential to break the Moslem monopoly on African trade. This article deals with precolonial Portuguese shipwrecks off the South African coast, engaged in trade voyages during Portugal's dominance of the Indian ocean route to India.

Keywords: Algoa Bay, Bartolomeu Dias, Chinese porcelain, Mozambique, Padrao.

\section{Introduction}

THE original logbook kept by Bartolomeu Dias is lost, but we are indebted to the Portuguese chronicler Joao De Barros for the earliest known record of the voyage. The record of Dias voyage is described in his epic work History of the Portuguese Conquest of Asia. Voyaging south of Cape Cross, Dias laid the first of three padraos, which he dedicated to Santiago on a headland on the west coast. After battling heavy winds, near Cape Voltas, Dias was forced out to sea in a southerly direction. After being driven eastwards, without finding land, he ordered the fleet to head north, making landfall a little west of Mossel Bay. Proceeding along the coast in an easterly direction, he arrived in Algoa Bay.

\footnotetext{
*e-mail: turnermj@telkomsa.net
}

At this point in his story, the seeds of confusion were sowed; Barros states that Dias placed a padrao on an islet, to which he gave the name da Cruz. The exact spot was on a sandstone headland called Kwaaihoek, which today is separated from the nearest bush by a $1 \mathrm{~km}$ wide dunefield. Today an island $4 \mathrm{~km}$ offshore inside Algoa Bay is erroneously called St Croix. The mistake was repeated by later chroniclers such as Vasco da Gama in his Roteiro of the first sea voyage to India in 1497-98 CE. He correctly states that the padrao set up by Dias is beyond the Ilheo da Cruz. Manuel de Mesquita Perestrello, in his survey of the coastline was also confused as to the identification of the island, stating that the island inside Algoa Bay is called St Croix, but correctly states that the cross, which was dedicated to Sao Gregory, was 'probably' placed on an islet east of the Chaos Islands (known today as Bird Island). The exact position of Dias's padrao has been positively identified and is about $80 \mathrm{~km}$ east of St Croix island, and fortunately, most of it has been recovered and preserved. It was first discovered by Robert Jacob Gordon, who was surveying the coast on behalf of the Cape Authorities in $1786 \mathrm{CE}$, and parts of it were taken to the castle in Table Bay, but the present-day location of these fragments is not known. In 1938 Eric Axelson found more pieces lying scattered down the cliff at Kwaaihoek. These fragments were taken to the University of the Witwatersrand in Johannesburg, where the cross was reconstructed and preserved. Today a replica of the cross has been erected on Kwaaihoek. Dias returned to Portugal after proceeding about $100 \mathrm{~km}$ further up the coast to a river he named the Infante. Here Barros records the following train of events: after leaving Kwaaihoek, which he called the Island of the Cross, the expedition came in view of Cape Point which he named Cabo das Tormento$s a$ (or Cape of Storms); they landed and erected their third padrao. He records that on their return to Portugal the name was changed by king Joao II to Cabo da Boa Esperanca (or Cape of Good Hope), in anticipation of the riches which were expected to flow from the Indies. Many researchers have tried to change Barros' record, stating that the name Cabo da Boa Esperanca was given to it by Dias, but Barros remains the only source document available, and until concrete proof is obtained, I believe we should accept the Barros account. In conclusion, 
it can be believed that Kwaaihoek should be named $\mathrm{St}$ Croix and that Dias did indeed give the name Cabo Tormentosa to Cape Point.

\section{Six pre-colonial Portuguese wreck sites on the South African coast}

A common thread in most of these stories is the desire of the survivors to reach Mozambique, where they had a fair chance of being rescued by Portuguese vessels. The Portuguese tended to steer clear of the South African coast, as they had not managed to form good relationships with the locals. Another interesting point is that all these vessels were homeward bound, most having been away from the repair yards in Portugal for a few years. If they were delayed in rounding Cape L'agulhas during the safe window period, they would have encountered the notorious winter 'cold fronts', with the result that any structural defects would be revealed.

Another problem was that their heavy cargoes could shift, thereby destabilizing the vessel further. The coast was remote, and shipwreck survivors' chances of survival were minimal. Many of the passengers were at an advanced age, and unfit to undertake a long walk to Mozambique. An exception to this rule is the Sao Joao Baptista, which wrecked after a fierce sea battle with two Dutch East-Indiamen. Most of the following wrecks were discovered when divers searched the seabed opposite sites, where Chinese porcelain sherds or other wreckage had washed ashore (Figure 1).

\section{Sao Joao (1552 CE) (31 902'42", $81 S$ and $\left.30^{\circ} 14^{\prime} 06^{\prime \prime}, 71 E\right)$}

A Portuguese East-Indiaman (galleon) commanded by Manuel de Sousa Sepulvida, wrecked on the south coast of Natal, a little to the north of Mtamvuna River on 11 June 1552 CE after being disabled in a storm. She was on a homeward bound voyage from Cochin, India, travelling in the company of Sao Jeronymo, which also wrecked,

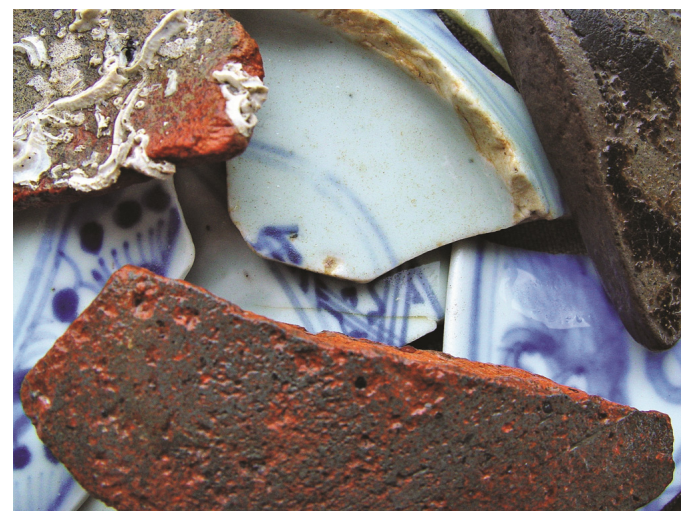

Figure 1. Chinese porcelain sherds and fragments of Martaban jars from Sao Bento (Martaban fragment approximately $10 \mathrm{~cm}$ ). (M. Turner). further north on the Zululand coast. Of the more than 200 Portuguese and more than 400 slaves on board, over 100 were drowned. The survivors walked to Delagoa Bay (Maputo), more than $618 \mathrm{~km}$ away ${ }^{1-3}$. They were later rescued by boat and taken to Mozambique. The survivors of Sao Bento recorded passing the wreck site almost two years later in $1554 \mathrm{CE}$. The wreck site has been identified by the presence of Chinese porcelain sherds and beads, and a cannon fragment, but little is to be seen due to the exposed and sandy conditions at the site.

\section{Sao Bento (1554 CE) (31 19'36", 45S and $\left.29^{\circ} 58^{\prime} 10^{\prime \prime}, 87 E\right)$}

A Portuguese East-Indiaman (nao) of 22 guns, commanded by Fernao D. Alvares Cabral wrecked at the mouth of a gulley on the seaward side of the 'island', a little west of the Msikaba River mouth on the Pondoland coast. The vessel was on a homeward bound voyage from Cochin to Lisbon, and was disabled in a storm on $21 \mathrm{st}$ April $1554 \mathrm{CE}$. The cargo consisted of pepper, cotton, Chinese porcelain, coconuts, silk and spices packed in 72 crates. Forty-four Portuguese and over 100 slaves lost their lives; 98 Portuguese (including Manuel de Mesquita Perestrello) and 224 slaves landed safely and travelled overland to Delagoa Bay (Maputo), over $640 \mathrm{~km}$ away, but only a few made it. They passed the Sao Joao wreck site $(1552 \mathrm{CE})$ on the way $^{4-6}$. A great deal of broken porcelain has been found among the rocks on the island (Figure 1) and eighteen bronze cannons have been recovered from the seabed. Other finds included lead coated iron shot, gold jewellery (Figures 2 and 3), a few

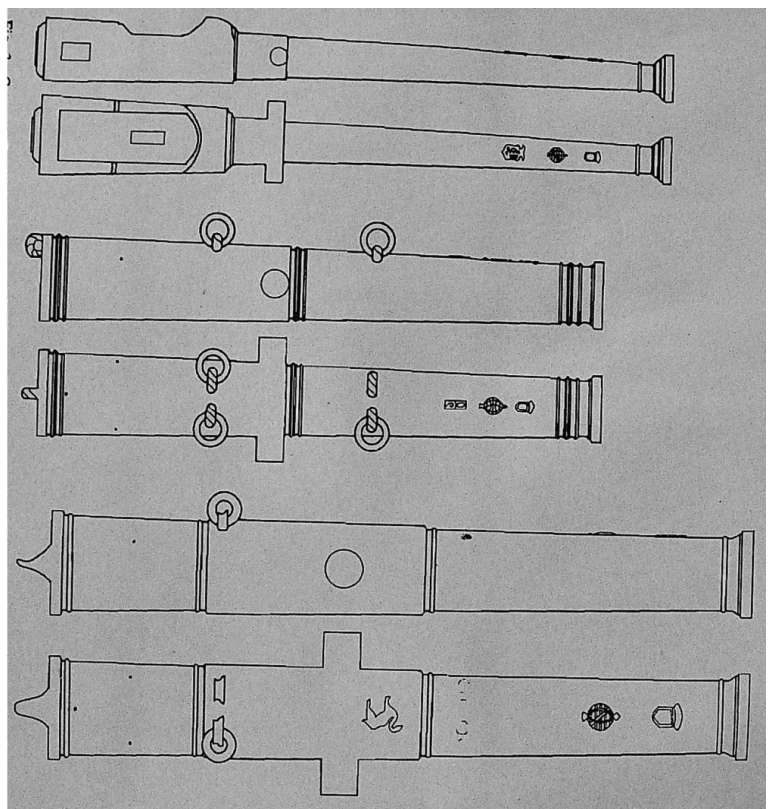

Figure 2. Bronze cannons recovered from Sao Bento site. The muzzle loaders have lifting lugs fashioned as rings as compared to the lifting dolphins cast into Atalaia and Sacramento guns. (Annals of the Natal Museum.)

CURRENT SCIENCE, VOL. 117, NO. 10, 25 NOVEMBER 2019 
Portuguese gold coins and many trade beads ${ }^{1,4}$. The site has been well documented by the personnel of the Natal Museum, who took the initiative to work closely with the divers who initiated the salvage work, and most of the guns have been preserved.

\section{Sao Joao Baptista (1622 CE) (33 $45^{\prime} 10^{\prime \prime}, 83 S$ and $26^{\circ} 32^{\prime} 46^{\prime \prime}, 33 E$ )}

A Portuguese East-Indiaman (nao) commanded by Capt. Pedro de Moraes Sarmento ran ashore near the Fish River in October $1622 \mathrm{CE}$ while on a homeward voyage from Goa, from where she departed on 1 March 1622 CE. The vessel was carrying a cargo which included a packet of diamonds, Chinese porcelain, cloth, carpets and pepper. Sao Joao Baptista was travelling in the company of the flagship Nossa Senhora do Paraiso. She had been involved in a prolonged sea battle with two outward bound Dutch East Indiamen, and as a result was in a sinking condition. The crew, passengers and trade goods were landed, but 18 lives were lost. The survivors set fire to the hulk to recover some ironwork to be used as trade items, and began the long walk to Inhambane in Mozambique, over $1400 \mathrm{~km}$ away. They were forced to leave many women and children at African villages on the way $^{7-9}$. Chinese porcelain sherds are regularly found on the beach opposite the position where two iron muzzle loadings guns were recovered from the rocks at low tide. Some more cannons are lying on the seabed opposite this site. There is strong evidence to support this identification as Robert Jacob Gordon reported the guns in $1786 \mathrm{CE}$, which provides a terminus ante quem. As there are no other recorded shipwrecks before $1786 \mathrm{CE}$, in the area, this must be Baptista.

\section{Sao Goncalo (1630 CE) (34 95 '44", 86S and} $\left.23^{\circ} 22^{\prime 3} 3^{\prime \prime}, 67 E\right)$

A Portuguese East-Indiaman commanded by Fernao Lobo de Meneses wrecked at the Piesang River mouth in

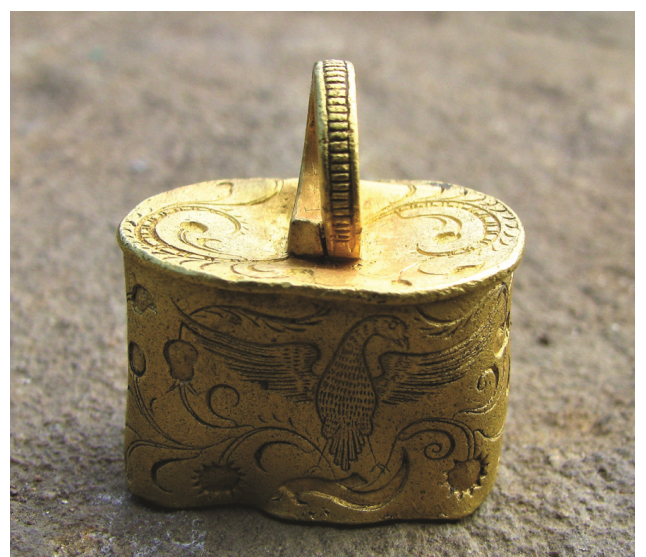

Figure 3. Small gold object from Sao Bento (approximately $2,5 \mathrm{~cm}$ ).
Plettenberg Bay in July 1630 CE during a storm while on a homeward bound voyage from Goa, from where she had departed on 4 March $1630 \mathrm{CE}$, to Lisbon with a cargo of spices, rice and Chinese porcelain. Sao Goncalo had put into the bay for repairs to her hull caused by a violent westerly gale in mid-ocean. The ship was leaking badly, and it was feared that the water would soon gain on the pumps. After battling for 50 days to effect repairs, a violent south-easterly gale sprang up, and the vessel was driven ashore and broke up in the surf line, causing the loss of 133 souls who had remained on board to do the repair work. Those who were camping on the shore used the timber of the wrecked vessel to build two pinnaces. One made it safely to Mozambique, and the other was picked up by a homeward bound vessel, Santo Ignacio Loyola, but she was later wrecked on the bar at Lisbon, resulting in the drowning of most of the Sao Goncalo survivors on board. The survivors' shore camp was found during building excavations near the Robberg Peninsula in 1981 (refs 10,11). A team of archaeologists recovered a large quantity of broken porcelain (Figure 4), a coin from Portuguese India, lead musket balls, utensils fashioned from mother of pearl shell and a Roman Catholic medallion. This site lies directly in front of the position of a modern steel shipwreck, Athina (1967 CE). It is highly probable that Athina lies on top of the site, and the presence of this large steel wreck probably accounts for the lack of success of various underwater magnetometer searches for the Sao Goncalo. As the wreck has not been excavated, no guns have been recovered.

\section{Nossa Senhora De Atalaia do Pinheiro (1647 CE), (32 $47^{\prime} 52^{\prime \prime}, 10 S$ and $\left.28^{\circ} 10^{\prime} 03^{\prime \prime}, 72 E\right)$}

A Portuguese East-Indiaman (nao), built in Portugal of pine sheathed with lead, under the command of Captain Antonio de Camara de Noronha, wrecked near the Cefane River $34 \mathrm{~km}$ north-east of East London in June $1647 \mathrm{CE}$ while on a homeward bound voyage from Goa to Lisbon. The vessel was sailing in the company of Santissimo Sacramento (which wrecked during the same storm about $280 \mathrm{~km}$ south-west at Schoenmakerskop west of Port Elizabeth); the vessel was carrying a full cargo which included pepper, a packet of diamonds, spices, Chinese porcelain and bronze guns from the Bocarro foundry in Macao. It had sprung a leak in mid-ocean after firing a seven gun salute in honour of the Commodore who was travelling on Sacramento. Shortly afterwards a strong south-westerly gale came up, and she was parted from Sacramento and was brought to anchor off the mouth of Cefane River. A strong swell came up and she was soon pounded to pieces by the heavy surf breaking on the beach. Many lives were lost, and after recovering in a makeshift camp onshore, the survivors set out on the long march north-east to Delagoa Bay (Maputo), about $873 \mathrm{~km}$ 


\section{SPECIAL SECTION: SHIPWRECKS}

away; they were later joined by the remaining survivors from Sacramento ${ }^{12,13}$. Commercial divers discovered the wreck in 1980, and 23 bronze muzzle loading cannon, including many Bocarro guns (Figure 5), a wrought iron anchor and an iron muzzle loading cannon was recovered from the seabed. The East London Museum worked closely with the salvage team and recorded the finds, and most of the guns have been preserved. Many porcelain fragments are regularly found on the beach opposite the wreck site.

\section{Santissimo Sacramento (1647 CE) (34 $02^{\prime} 16^{\prime \prime}, 72 S$ and $25^{\circ} 31^{\prime} 14^{\prime \prime}, 96 E$ )}

A Portuguese East-Indiaman (nao) of 1000 tonnes, built of teak at Bassein, India, by Rui Dias da Cunha was wrecked in Cannon Bay, a little west of Schoenmakerskop, on 1 July 1647 CE. Her rudder was damaged while on a homeward bound voyage from Goa to Lisbon in the company of Nossa Senhora de Atalaia, which wrecked at the Cefane River mouth, about $280 \mathrm{~km}$ north-east. Onboard was the commander of the fleet, Luis de Miranda Henriques. The vessel was carrying a full cargo which included pepper, spices, a package of diamonds, Chinese porcelain and a consignment of bronze artillery cannon

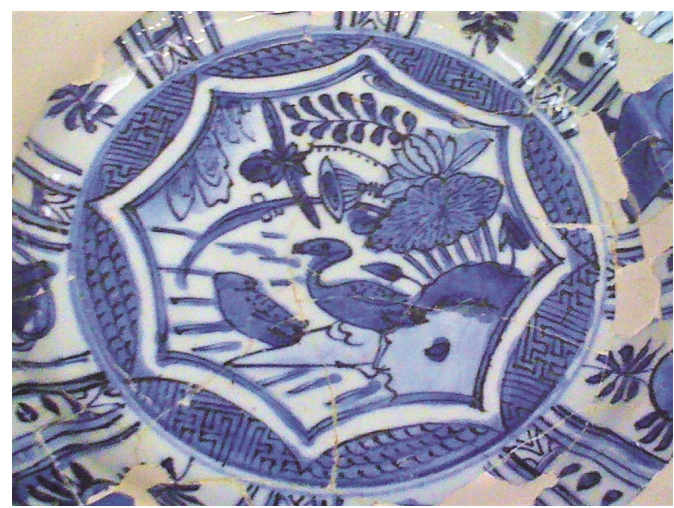

Figure 4. Broken Chinese porcelain plate, found in the survivors camp of Sao Goncalo (central motif approximately $12 \mathrm{~cm}$ ).

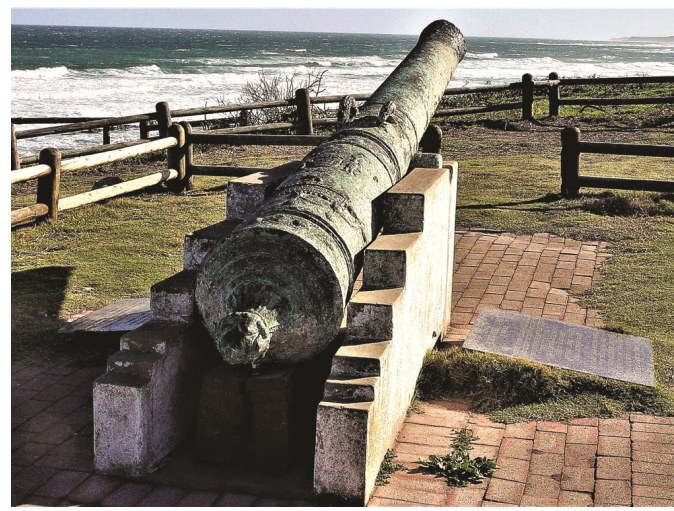

Figure 5. A bronze artillery gun from the cargo of Sacramento, cas in Macao by Manuel Tavares Bocarro in 1640, similar guns were found on the site of Atalaia. (M. Turner). from the Bocarro foundry in Macao (Figure 5). More than forty bronze muzzle loading cannons have been recovered including many ships' guns. About 17 cast iron guns remain on the site, and three anchors are lying in shallow water inshore. There was heavy loss of life, and the few able survivors began walking to Delagoa Bay, about $1100 \mathrm{~km}$ away. Many died on the way, and the remainder met up with the survivors of Atalaia and continued with them ${ }^{12,13}$. The wreck site was first visited by Colonel Robert Jacob Gordon in $1778 \mathrm{CE}$ and recorded in his journal, which provides a terminus ante quem; since then, commercial salvage divers have recovered the guns from the seabed.

As is apparent, salvage work was carried out at these shipwreck sites before the introduction of protective legislation in South Africa. Therefore, much of the credit goes to the museum personnel, and the divers involved in these ventures who recorded the facts and artefacts salvaged.

1. Annals of the Natal Museum, Pietermaritzburg, Natal Museum, December 1984, vol. 26, Part 1, pp. 173-186.

2. Relacao Do Naufragio Do Galeao Grande S. Joao Na Terra Do Natal No Anno De 1552, Lisboa Occidental, Na Officina da Congregacao do o Rotario, 1735.

3. Theal, G. M., (tr.) Records of South Eastern Africa, William Clowes \& Sons Ltd, Government of Cape Colony, London, 1898, vol. 1 , pp. $128-149$

4. Annals of the Natal Museum, Pietermaritzburg, Natal Museum, October 1982, 25 Part 1, pp. 1-39.

5. De Mesquita Perestrello, Manuel, Relacao Do Naufragio Da Nao S. Bento, Lisboa Occidental. Na Officina da Congregacao do o Rotario, 1735.

6. Theal, G. M. (tr.), Records of South Eastern Africa, William Clowes \& Sons Ltd, Government of Cape Colony, London, 1898 , vol. 1, pp. 218-285.

7. Bruin, J., Gaastra, F. and Schoffer, I., Dutch-Asiatic Shipping Outward Voyages, The Hague, 1979, pp. 1595-1794.

8. Almada, Francisco Vaz d, Tratado do sucesso que teve a nao Sam Ioam Baptista, Lisbon, 1625.

9. Theal, G. M. (tr.), Records of South Eastern Africa, William Clowes and Sons Ltd, Government of Cape colony, London, 1902, vol. 8, pp. 69-137.

10. De Faria Y. Sousa, Manuel, Asia Portuguesa, Lisbon, 1675, vol. 3.

11. Theal, G. M. (tr.), Records of South Eastern Africa, William Clowes and Sons Ltd, Government of Cape Colony, London, 1900, vol. 6, pp. 411-421.

12. Feyo, Bento Teyxeyra, Relacam do Naufragio que fizeram as Naos Sacramento \& nossa Senhora da Atalaya vindo da India para o Reyno, no Cabo de Boa Esperanca, Lisbon, 1650.

13. Theal, G. M. (tr.), Records of South Eastern Africa, William Clowes and Sons Ltd, Government of Cape Colony, London, 1902, vol. 8, pp. 295-360.

ACKNOWLEDGEMENTS. I acknowledge archaeologists, historians, researchers and commercial divers namely: the late Gill Vernon and Graham Bell Cross of East London, Dee Nash and the late Alf Porter of Port Elizabeth and the staff members of the Natal Museum in Pietermaritzburg. I also thank Dr Sila Tripati for inviting my contribution to this special section. Finally, I pay tribute to Peter Sachs formerly of East London for his open policy of sharing information, and of course, the original team who discovered and salvaged the Sao Bento. Without these working partnerships, much valuable historical information would have been lost.

doi: $10.18520 / \mathrm{cs} / \mathrm{v} 117 / \mathrm{i} 10 / 1683-1686$ 